\title{
Corporate Characteristics and Influence on Share Based Payment of Financial Service Firms in Nigeria
}

\author{
Davies, Stanley Diepiriye ${ }^{1} \&$ Lucky, Anyike Lucky ${ }^{1}$ \\ ${ }^{1}$ Department of Accountancy, Ken Saro-Wiwa Polytechnic, Bori, Rivers State, Nigeria \\ ${ }^{2}$ Department of Banking and Finance, Rivers State University, Nkpolu Orowurokwo, Port Harcourt,Rivers State, \\ Nigeria. \\ Correspondence: Davies, Stanley Diepiriye, Department of Accountancy, Ken Saro-Wiwa Polytechnic, Bori, Rivers \\ State, Nigeria.
}

Received: January 19, 2018

Accepted: January 22, 2018

Online Published: January 27, 2018

\begin{abstract}
This investigates the effect of corporate characteristics on share base payment of financial service industry in Nigeria. Objective of the study is to if internal factors affects share base payments of corporate organizations in Nigeria. We analyzed five commercial banks and five insurance firms that are quoted on the floor of Nigerian Stock Exchange. Technique adopted for sampling adopted is convenience sampling. As the nature of data is panel therefore, pooled regression, fixed and random effect tests are run. Random effect results are focused after applying Hausman's test. From the fixed effect model, tangibility, risk, management efficiency, debt equity ratio, corporate governance and cost of capital have negative but insignificant effects while return on investment, liquidity and firm size have positive and insignificant effect on share base payment. We conclude that corporate characteristics does not significantly influence share base payment of the selected financial service firms. We therefore recommend that the use of share base payment should be integrated with the corporate structure such as ownership structure, capital structure and others.
\end{abstract}

Keywords: Share Base Payment, Corporate Characteristics, Financial Service Firms, Agency Theory, Corporate Payout Policy.

\section{Introduction}

The traditional finance paradigm, theory and teaching put the shareholders wealth maximization as the primary goal of corporate management. The shareholders wealth maximization as function of management is a critical function that requires tactical and strategic measures to achieve. Apart from maximizing shareholders wealth as finance theory formulated, the corporate organization has obligations such as payment to employees and creditors. These can be raid in cash or share base payment. The emergence of share base payment dates back to the 1920s when it highlighted a change in ownership of the company. Due to an increasing number of private investors that became interested in the Stock Exchange and in yield investments, the separation of ownership and control of the companies started (Zhou, 2010). Share based payment issued by International Accounting Standard Board is regulated by International Financial Reporting Standard. This standard addresses payments and compensation plans which have been more and more accepted and adopted. Alexander et al. (2007) noted that bonus and profit sharing plans have for a long time been the only widely used instrument to increase compensation for executives and employeesll. However, from the beginning of 1990 s stock based compensation, or more broadly share-based payments, became very popular (Hall and Liebman, 1998). Share based payment awards are an integral component of a total compensation package. As such, they concluded that an entity should recognize an expense for share-based payments, just as it does for cash compensation (Ross, 2004).

International Financial Reporting Standard 2 distinguishes between the accounting treatments for share-based payment transactions of equity-settled versus cash-settled. A transaction is treated as equity-settled when an entity receives goods or services as consideration for its own equity instruments (including shares or share options), or it receives goods or services but has no obligation to settle the transaction with the supplier. Additionally, increased 
competition adds special concern and is considered a problematic issue. It is a must for firms to find alternative solutions in order to increase performance and be efficient. Share based payment seems to present a paradox in terms of giving contribution to firms. Its use may relate to some firm's characteristics and it may represent important and relevant information to owners and management. The negative sidell regarding the use of share based payment related to an opportunistic behavior which may be replaced once potential users of this incentive remuneration plan are aware of the benefits of its use when appropriated. That is the reason why studying the determinants of share based payment use plays a significant role (Johnston, 2006). (Duncan, 2001) noted that a major proposition of the agency theory is that the conflict of interests between an agent and a principal is reduced when the agent's wealth and compensation are tied to the performance of the firm. Apart from the direct predicted relation to corporate performance, compensating managers with equity instruments has implications for corporate risk-taking and payout policy choices. Additionally, equity-based compensation practices are to a large extent shaped by institutional factors, such as accounting regulations and corporate characteristics ( Baker, Collins and Reitenga, 2009).

Empirical studies concerning share based payment is made by the discussion regarding the role and motivation for the use and effects of share based payment. However, there are limited studies of citable significance that have death with corporate factors that determine share based payment not much focus has been made on the determinants of share based payment, especially when it comes to knowing about companies' characteristics influence on implementation of such plan. Existing studies have failed to conclude on factors that determine share based payment and the direction of causality. The importance of looking at the determinants is that it shows the users including owners and managers a way in which share based payment is used as an efficient tool for motivation and monitoring, it is interesting to investigate how corporate characteristics are associated to share based payment. Connecting the share based payment use with corporate characteristics and finding certain patterns of determinants for its application, provides relevant information regarding what kind of corporate characteristics is a predictor for the use of share based payment as an efficient tool. Thus, understanding the determinants bring advantages for the users as it helps them to know in which way the use of share based payment can be a good alternative for other remuneration plans(Frydman and Saks, 2010). Therefore this study intends to examine corporate characteristics and share based payment of financial service firms in Nigeria. Section two focuses on both theoretical and empirical review of related literature, section three deals with the research methodology. Section four deals with the data analysis and presentation and the fifth section contain the conclusion and recommendations from the findings.

\section{Literature Review}

Share Based Payment

Share-based payment is defined as transactions in which an entity receives goods or services in exchange for equity instruments. IFRS 2 makes the following categorizes of share based payment:

Equity Settled Share Based Payment

In this category of Share-based payment plan share, share options and other equity instruments are transferred to directors, senior executives and other employees. There are different types of share options including, call options, subscription options, synthetic options, and convertibles. An example brought by Alexander et al. (2008) is used to illustrate this kind of transaction and this is when top executives or/and employees receive as part of remuneration, shares, options or other equity instruments. This can be received through different kind of compensation plans including, employee stock option plans (ESPs), and employee stock purchase plans (ESPPs), restricted stock plans, and employee stock ownership plans (ESOPs).

Cash Settle Shared Based Payment Transaction

In this transaction the entity shall measure the services acquired and the liability incurred at the fair value (FV) of the liability. The amount will depend on the future market price of the equity instruments as part of a remuneration plan. Until liability is settled the entity shall measure the FV of the liability at each reporting date with any changes in the FV of the liability is recognized in profit or loss account. The amount of cash to be received will be determined by the value of the option at the exercise date.

Alternatives Cash or Share Options

In this transaction it is up to the counterparty or the entity to choose the settlement of the Share-based payment. In this case the entity grants the counterparty the right to choose whether share-based transaction is done by cash or by issuing equity instruments.

Disclosure of Share Based Payment

The main disclosure requirements for stock option plans are mentioned in the standards (IFRS 2 and FAS 123). Besides that further requirements may be needed in different countries based on their own codes of corporate governance. The requirements that are provided by IFRS 2 for disclosure include the nature and the extent of sharebased payment arrangements during the period, information about the fair value of the equity instruments and how it is achieved, and the effect of the share-based payment transactions on the financial position and profit/loss of the 
entity. The standard requires that a detailed description of all share-based payments should be disclosed. This includes all different types of share-based arrangements and their conditions, all the information about the granted options including, number of options at the beginning of the year and outstanding options at the end of the year, number of granted options, exercised options and expired options, weighted average exercise price of options and all the detailed information for this transaction which can have an impact on the decision of the users of financial statements.

The information should be disclosed in the financial notes in the annual reports.

Theoretical Framework

Efficiency Perspective

Efficiency perspective explains that different accounting methods and policies are used to reflect the underlying performance of the firm in the efficient way. Deegan and Unerman, (2006) state this theory can also explain why a particular method is implemented inside companies with different organizational characteristics. This perspective is very close to this research as we observe different characteristics of the companies and see the relation that they have with the implementation of Share-based payment plan. This perspective can be closely related to the agency theory explained by Jensen and Meckling (1976). They argue that this practice can lead to cost saving. Based on this perspective the adoption of this plan is based on the management consideration for solving the agent problem and enhancing the performance of the company. Deegan and Unerman, (2006) refer this view usually to ex ante perspective which means the mechanism is put in the place to minimize the future cost of an/the agent.

Advocates of this perspective express their arguments through different theories. The pioneers in this area are Jensen and Meckling (1976), and Jensen and Murphy (1990). Some argue that use of Share-based payment can motivate management to choose a method that helps to reduce the agency cost. The reason is that, firms will be allowed to choose those accounting methods that best reflect the performance of the firm. It would be argued that management is best able to select which accounting methods are appropriate for the special situation. Therefore, use of SBC is considered as the most effective tool in pay-performance relation. Another related argument for supporting this perspective is that this method can also solve the information asymmetry by giving the principle an opportunity to monitor the agent. In this context, Share-based payment is a bridge which can bring efficiency for both sides of this bridge, principal and agent.

Opportunistic Perspective

An alternative perspective is based on this idea that in choosing particular accounting methods there are other objectives which is driven by self-interest. Deegan \& Unerman (2006), consider this perspective as a practice of creative accounting. This means that a specific method is applied in the situation where accounting methods are selected based on the intention of the people who are responsible for the preparation of accounts. This perspective is referred as ex post perspective which means after the fact, because it considers opportunistic behavior, after all are arranged in a contractual arrangement.

Hence, some of the bonus plans including profit based compensation and Share-based payment have been blamed for this opportunistic perspective. Advocates of this perspective believe that use of this method can attract managers to elect to adopt particular accounting methods whenever they believe that this will lead to an increase in their personal wealth. Furthermore, according to Faulkender et al. (2010), an effective pay package is not necessarily the one most laden with equity incentives, since too much equity exposure can cause excessive risk-taking, manipulation, and shift executive attention away from true value creation. This is why they state that based on this theory for choosing particular accounting methods management is opportunistic. The techniques that are known in accounting as opportunistic behavior are earning management and off balance sheet funding.

This perspective is studied by many authors in our survey and is based on the idea that the separation between ownership and management might give managers substantial power. This gain of power may result in side effects of such compensation plans. This issue is addressed for example by Alexander et al. (2007), Peng and Röell (2008), Blasi et al. (1996), Cheng and Warfield (2004), Core and Guay (2001), and Yermarck (1997). They all have the common argument that using Share-based payment and thus addressing the agency problem by granting executives may induce managers to act in an inappropriate manner. Blasi et al. (1996) are against the empowerment of the executives, instead they prefer and defend that the workforce should be the ones included in such programs, acting like owners increase profitability performance and productivity.

Agency Theory

An agency relationship is established when a principal delegates a decision making responsibility in a firm to an agent. Although a natural and inevitable stage in the evolution of the corporation, the resulting separation of ownership from control leads to an agency conflict, because the controlling mangers, whose actions are unobservable, may be tempted to pursue their personal goals when running a company. Such a moral hazard 
behavior may take a variety of forms, including overconsumption of perquisites, diversion of corporate resources and exertion of insufficient effort.

This problem, recognized already by Smith (1776) and described in greater detail in Berle \& Means (1932), is at the core of the two central theoretical frameworks for studying executive ownership and compensation. The first line of research approaches the agency problem by contemplating managerial equity claims in the context of the ownership structure of the firm. Jensen \& Meckling (1976) compare the behavior of a manager when she owns $100 \%$ of equity claims of the firm to the situation when she sells off a portion of these claims to outside shareholders. Using an example with non-pecuniary benefits they demonstrate, that while a partial manager-owner enjoys the full benefits of perquisite consumption, she bears only a portion of the associated costs equal to her partial ownership. The investors anticipate the overconsumption of perquisites by a manager and factor the associated agency costs into the price they are willing to pay for the stock. Within this framework the manager's fractional ownership represents a measure of severity of the agency conflict. The intuitive prediction of this theory is that with an increase in managerial ownership the interests of an agent and a principal become aligned, thereby inducing the agent to act in the best interests of a principal.

Although not ignoring the existence of the agency problem arising from managerial self-serving behavior, several studies criticize the theoretical grounds of the "incentive alignment" hypothesis by relying on market efficiency reasoning. Demsetz \& Lehn (1985) develop the so-called optimal contracting theory by arguing that the observed firm ownership structure is an endogenous outcome of a competitive selection in which costs and benefits are balanced to arrive at the equilibrium organization of the firm. In other words, the survival of the dispersed ownership implies that the benefits of this organizational form outweigh the costs to the shareholders and that the observed firm ownership structure is value-maximizing. In this context the degree of managerial self serving behavior becomes irrelevant and no relation between fractional ownership and firm value should be expected ex ante. These arguments emphasize the importance of considering the endogenous nature of managerial fractional ownership in the empirical tests. Accordingly, when attempting to control for the endogeneity in the relationship between managerial ownership and firm performance, some studies have failed to find a positive relationship between the two (Demsetz \& Lehn 1985, Himmelberg et al. 1999).

Corporate Payout Policy

Managerial equity ownership is related to the corporate payout policy in the following ways. First, it can mitigate a free cash flow problem, which arises when an entrenched manager spends internally generated cash flows on value destroying projects instead of returning the funds to investors via dividends and share repurchases (Jensen 1986). If higher managerial ownership aligns the interests of managers and shareholders, firms in which managers hold more equity are expected to have greater payouts. Testing this prediction, Fenn \& Liang (2001) find that managerial stock ownership is associated with higher payouts, but only in firms characterized by the greatest agency problems those with low managerial ownership and scarce growth opportunities. Second, executive stock- and option holdings have different implications for the composition of the corporate payout.

The value of non-dividend protected options, however, decreases with the dividend yield, as is also evident and holders of such options forego dividends which they could otherwise receive were the options converted into shares. Thus, ceteris paribus, executives holding more options are expected to have a greater preference for stock repurchases relative to dividends as a form of corporate payout. In contrast, shareholdings capture both the dividends and value increases from stock repurchases to the same extent. The managers, however, are often restricted from selling their shares (Core \& Guay 1999) and may not be able to immediately benefit from the share repurchases. In this respect, executives with greater shareholdings may favor dividends over repurchases as a form of corporate payout for personal liquidity reasons. These theories fail to explain Nigeria issues.

Empirical Review

Frydman and Saks (2010) examine long-term executive compensation trends using an extensive dataset of large firms from 1936 to 2005. Their results agree with those of Hall and Liebman (1998), finding a large increase in payto-performance based on two measures, the Jensen-Murphy statistic and the value of equity at stake, during the 1980s and 1990s. Nagar et al. (2003) approach the issue of incentive alignment through stock-based compensation by focusing on disclosure agency problems. Their main argument is that managers are more likely to communicate their private information to shareholders if their compensation is tied more closely to the firm's equity value. Otherwise, managers are not willing to reveal their private information because of the possible private benefits of retaining such information.

Zhou (2001) the firm fixed effect specification employed by Himmelberg et al. (1999) was unlikely to be powerful enough, because managerial ownership changes vary slowly over time, rendering detection of any positive relationship impossible. With these caveats in mind, the subsequent studies in this area focus on refining econometric models, by both taking into account the endogeneity between managerial ownership and firm 
performance and attempting to overcome a problem of insufficient intertemporal variation in the levels of ownership. McConnell et al. (2008) approach the problem by investigating a short-term market reaction to increases in insider ownership resulting from share purchases and find a curvilinear relationship. Fahlenbach \& Stulz (2009) examine the effect of large changes in managerial ownership on firm value and report an asymmetric relation: large increases in ownership increase firm value, while large decreases are not related to firm performance. Benson \& Davidson (2009) investigate the relation between the dollar value of managerial ownership and firm performance by justifying their choice of ownership measure with the argument that the dollar value of ownership varies to a greater extent over time than the fractional ownership.

Fenn \& Liang (2001) find that firms with greater managerial option holdings increase repurchases at the expense of dividends. Kahle (2002) reports that companies decide to repurchase options both in order to offset share dilution from broad-based option plans and when managerial wealth is expected to be adversely impacted by the dividend payments, that is, when managers hold many options. Cuny et al. (2009) find that executive stock options are associated with lower total payouts and conclude that incentives from the lack of dividend protection of options dominate those related to the anti dilution effect of broad based option plans in the decision on the magnitude of a total corporate payout. Brav et al. (2005) find little support for the notion that companies prefer repurchases over dividends because employee stock options are not dividend protected. With respect to the prediction that managerial stock ownership encourages payouts in the form of dividends,

Brown et al. (2007) report that companies in which managers held large amounts of shareholdings increased dividend payments following the enactment of the Jobs and Growth Tax Relief Reconciliation Act in 2003, which reduced the dividend tax rate from $38.6 \%$ to $15 \%$. The findings regarding an impact of executive ownership structure on the corporate payout policy generally suggest that executives view dividends as an important component of their personal firm-related income. The role of this dividend income in the executive compensation decisions is studied in the fourth essay.Nagar et al. (2003) use two measures to proxy for the extent of these disclosures: the frequency of management earnings forecasts and analysts' ratings of disclosures taken from the Association for Investment Management Research survey. Consistent with their conjecture, both measures are found to be positively associated with the proportion of CEO pay linked to stock prices. Voluntary disclosures may also reduce the contracting costs associated with stock-based compensation. New employees whose remuneration is tied to stock prices will require extra compensation for the additional risk they bear in case of mispriced company stock. Thus, firms that heavily rely on stock-based compensation schemes are more likely to make voluntary disclosures to reduce the information asymmetry between managers and shareholders (Healy \& Palepu, 2001).

Barth (2003) questions the actual benefits that shareholders gain from more frequent managerial disclosures because stock-based compensation can also incentivize managers to distort such disclosures. Aboody and Kasznik (2000) found that managers release self-serving forecasts to maximize the value of their stock option awards by announcing bad news and delaying good news around the award date. Shareholders may not use the information from managerial disclosures if they do not know whether the managers reveal true information.

Cheng and Lo (2006) report that managers engage in more selling activities during periods of increased disclosures of bad newsman, Noe (1999) also indicates that insider trading tends to follow management forecasts. However, managers will act in a subtle manner when capitalizing on private information due to legal restrictions on insider trading. Insider trading would be associated with less sensitive private information, such as the firm's long-term performance, rather than biased disclosures regarding short-term performance. In this case, shareholders will be able to learn about future performance either directly through the private information embedded in voluntary disclosures or indirectly by watching the managers' trading patterns (the informative disclosure argument). Smith \& Stulz (1985) and Milgrom \& Roberts (1992) suggest that the riskrelated agency problems are most severe in growing firms, therefore growing firms are supposed to provide managers with more convex compensation structures.

Guay (1999) reports that managers in firms with more valuable growth opportunities have greater risk-taking incentives, whereas greater managerial risk-taking incentives are associated with higher stock return volatility. This finding implies that convex compensation schemes affect the riskiness of investing and financing decisions. Coles $e t$ al.(2006) employ a simultaneous equations empirical research design and find that a higher vega implements riskier corporate policies, while at the same time riskier policy choices lead to compensation structures with higher vega and lower delta. The firm risky choices in their study are measures as higher R\&D investment, lower capital expenditures, higher leverage, narrower corporate focus and greater stock return volatility.

Low (2009) investigates how an exogenous shock to the corporate risk environment affects firm compensation policies and documents that companies respond to it by providing managers with greater risk-taking incentives. Chava \& Purnanandam (2010) extend this line of research by comparing the effect of risk-taking incentives of both a CEO and a CFO on the broad set of corporate policies and find that the predicted relations are present when a particular executive has a greater discretion over a specific corporate choice. Other studies investigate the effect of 

2012), risky financial reporting choices (Armstrong et al. 2013), volatility of idiosyncratic and systematic components of firm stock return (Armstrong \& Vashishtha 2012), and degree of hedging activity (Knopf et al. 2002, Rogers 2002). Ross (2004) shows theoretically that for a risk-averse manager the compensation schedule moves the evaluation of a given gamble to a different part of the domain of her original utility function, where the manager may be less or more risk averse. In other words, the agent assesses the risk from the perspective of being wealthier and this effect may offset the impact of the compensation convexity.

Lewellen (2006) takes into account the effect of managerial risk aversion and quantifies volatility cost of debt as a change in manager's certainty equivalent induced by changes is firm leverage. Her results suggest that stock options, especially that in-the money, discourage managerial risk-taking. Hayes et al. (2012) use these arguments to explain the lack of reduction in the riskiness of corporate investment and financing policies following an exogenous decrease in managerial vega incentives triggered by the adoption of. In sum, the role of option-based compensation in mitigating risk-related agency problem is not fully understood. From the literature, it is evidence that none of the studies examine the Nigeria situation and the findings of the studies failed to establish valid relationship between corporate characteristics and share based payment. This study therefore intends to examine the influence of corporate characteristics and share based payments in Nigeria

3. Research Methodology

This study intends to examine the influence of corporate characteristics on share based payment. Ex-post facto research design was employed in obtaining, analyzing and interpreting the relevant data for hypotheses testing. The rationale for the variety is that ex-post facto research design allows the researcher the opportunity of observing one or more variables over a period of time. Specifically, panel data were adopted in data analysis. The dataset employed in this study were generated from Nigeria Stock Exchange factbook and financial reports and statement of accounts of quoted financial firms in Nigeria. Firm annual statements and reports are deemed to be reliable because they are statutorily required to be audited by a recognized auditing firm before publication.

Panel data structure allows us to take into account the unobservable and constant heterogeneity, that is, the specific features of each quoted firm. The researcher employed pooled Ordinary Least Square (OLS), Fixed Effects and Random Effects regression models to test the various hypotheses. Pooled OLS egression technique is popular in financial studies owing to its ease of application and precision in prediction (Alma, 2011).

These analytical techniques will enable the researcher attain justifiable and robust results.

$\begin{array}{lll}Y=\beta_{0}+\beta_{1 \text { Xit }}+\mu & \\ \text { Where Y } & = & \text { Dependent Variable } \\ \beta_{1 \text { Xit }} & = & \text { Independent variable } \\ \beta_{0} & = & \text { Regression Intercept } \\ \mu & = & \text { Error Term }\end{array}$

Disaggregating Equation 3.1 to form the multiple regression models, we have

$S B P=F(D E R, C G, T A B, F S, C C, P F, M E, L I Q, R I S K)$

Transforming equation 3.2 to econometrics form, we have

$S B P=\beta_{0}+\beta D E R+\beta_{2} C G+\beta_{3} T A B+\beta_{4} F S+\beta_{5} C C+\beta_{6} P F+\beta_{7} M E+\beta_{8} L I Q+\beta_{9} R I S K+\mu$

Where $S B P=$ Share Base Payment as percentage of share based payment to total equity

$D E R=$ Debt Equity Ratio

$C G=$ Corporate Governance proxy by dummy variable

$T A B=$ Tangibility fixed assets to total assets

$F S=$ Firm Size proxy by log of total asset

$C C=$ Cost of Capital proxy WACC

$P F \quad=\quad$ Profitability Proxy by return on investment

$M E \quad=\quad$ Management Efficiency total cost to total revenue

$L I Q=$ Liquidity proxy by current asset to current liabilities

RISK = $\quad$ Risk proxy by variability of earnings

Formulating hypothesis from the above model:

$\mathrm{H}_{01}$ : There is no significance relationship between debt equity ratio and share base payment

$\mathrm{H}_{02}$ : There is no significance relationship between corporate governance and share base payment 
www.cribfb.com/journal/index.php/asfbr

Asian Finance \& Banking Review

Vol. 2, No. 1; 2018

$\mathrm{H}_{03}$ : There is no significance relationship between tangibility and share base payment

$\mathrm{H}_{04}$ : There is no significance relationship between firm size and share base payment

$\mathrm{H}_{05}$ : There is no significance relationship between cost of capital and share base payment

$\mathrm{H}_{06}$ : There is no significance relationship between profitability and share base payment

$\mathrm{H}_{07}$ : There is no significance relationship between management efficiency and share base payment

$\mathrm{H}_{08:}$ There is no significance relationship between Liquidity and share base payment

$\mathrm{H}_{09}$ : There is no significance relationship between risk and share base payment

Formulating model for hypotheses testing

Hypothesis I

SBP =

$$
\beta_{0}+\beta_{1} D E R+\mu
$$

Hypothesis II

SBP =

$$
\beta_{0}+\beta_{2} C G+\mu
$$

Hypothesis III

SBP $=\beta_{0}+\beta_{3} T A B+\mu$

Hypothesis IV

$\mathbf{S B P}=\beta_{0}+\beta_{4} F S+\mu$

Hypothesis V

SBP =

$$
\beta_{0}+\beta_{5} C C+\mu
$$

Hypothesis VI

$\mathbf{S B P}=\beta_{0}+\beta_{6} P F+\mu$

Hypothesis VII

$\mathrm{SBP}=\beta_{0}+\beta_{7} M E+\mu$

Hypothesis VIII

$\mathrm{SBP}=\beta_{0}+\beta_{8} L I Q+\mu$

Hypothesis IX

$\mathbf{S B P}=\beta_{0}+\beta_{9} R I S K+\mu$

Null Hypotheses; $\mathrm{H}_{0}: \beta=0$, (Statistically not significant)

Alternate Hypotheses; $\mathrm{H}_{1}: \beta \neq 0$. (Statistically Significant)

And the decision rule states that " $\mathrm{H}_{0}$ " should be rejected when T-statistics is greater than the critical value. But when the T-statistics is lower than the critical value, the " $\mathrm{H}_{0}$ " is accepted with its conclusion.

\begin{tabular}{|c|c|c|c|}
\hline \multicolumn{4}{|c|}{ Redundant Fixed Effects Tests } \\
\hline Effects Test & Statistic & d.f. & Prob. \\
\hline Cross-section F & 1.587346 & $(9,41)$ & 0.1514 \\
\hline Cross-section Chi-square & 17.936983 & 9 & 0.0359 \\
\hline \multicolumn{4}{|c|}{ Correlated Random Effects - Hausman Test } \\
\hline Test Summary & $\begin{array}{l}\text { Chi-Sq. } \\
\text { Statistic }\end{array}$ & Chi-Sq. d.f. & Prob. \\
\hline Cross-section random & 14.286114 & 9 & 0.1125 \\
\hline
\end{tabular}

4. Presentation of Results and Discussion of Findings

Table 1: Test of Models

Source: E-view windows 9.0

For the purpose of decision making regarding choice between fixed and random effects Hausman test was run. The decision of choice between fixed and random effect is based on p-value of Hausman test. If the p - value of the Hausman test is less than 0.05, we have a preference to use a fixed effects model. On the other hand if the p-value of the Hausman test is more than 0.05 , we select to use fixed effects. In this study, the p-value of Hausman test was more than 0.05 so fixed effects are used. For comparison purpose pooled regression results are also given. Value may be shown as F-Value. "F" value of the table signifies whether the overall model is statistically significant or not. The more the $\mathrm{F}$ value or Wald chi square test value the more the model is considered not significant.

Table 2: Presentation of Results: The Pooled Effect 


\begin{tabular}{crrrr}
\hline Variable & Coefficient & \multicolumn{1}{l}{ Std. } & t-Statistic & Prob. \\
& & Error & & \\
\hline TAB & 0.232160 & 0.831262 & 0.279287 & 0.7812 \\
\hline ROI & 0.252097 & 0.278787 & 0.904263 & 0.3702 \\
\hline RISK & 0.006027 & 0.609468 & 0.009888 & 0.9921 \\
\hline ME & -0.227593 & 0.094745 & -2.402178 & 0.0201 \\
\hline LIQ & 0.001599 & 0.003008 & 0.531496 & 0.5974 \\
\hline FS & 0.011750 & 0.099352 & 0.118270 & 0.9063 \\
\hline DER & -0.097781 & 0.099465 & -0.983075 & 0.3303 \\
\hline CG & -0.977813 & 1.536550 & -0.636369 & 0.5274 \\
\hline CC & -1.329340 & 0.799668 & -1.662364 & 0.1027 \\
\hline C & 40.82592 & 12.40824 & 3.290227 & 0.0018 \\
\hline R-squared & 0.221080 & & & \\
\hline Adjusted R-squared & 0.080875 & Durbin-Watson stat & 1.768800 \\
\hline F-statistic & 1.576831 & & & \\
\hline Prob(F-statistic) & 0.148081 & & & \\
\hline
\end{tabular}

Source: E-view windows 9.0

One of the assumptions of the fixed effect model is that unique features of the entities ought not to be correlated with other distinct features. If the error terms are correlated then fixed effect is not considered a fit choice and the results may not be trustworthy and as a result random-effects will have to be used. The logical reason on the back of usage of the random effects model is that, in contrary to the fixed effects model, the variation in entities is assumed to be random and unrelated with the independent variables of the model. One of the merits of random effects is that invariable variables may be included. In fixed effects model these variables are absorbed by the intercept.

Table 2 show the details analysis of the pooled effect regression results on the effect of corporate characteristics and its influence on share base payment of financial service firms in Nigeria. Looking at results it is evidenced that the independent variables can explain $22.1 \%$ variation on the dependent variable which is the percentage of share base payment to total equity of the selected financial service firms. The F-statistics and the probability coefficient show that the model is not significant this means that the independent variables cannot significantly explain variation on the dependent variable. The T-statistics and probability coefficient of the independent variables indicates that all the variables are statistically not significant at $5 \%$ level of significance. The $\beta$ coefficient indicates that tangibility, return on investment, risk, liquidity, firm size have positive relationship with share base payment of the selected financial service firms while management efficiency, debt equity ratio, corporate governance and cost of capital have negative relationship with share base payment. The insignificant and negative impact of the variables could be traced to the fact that most corporate organizations in Nigeria does not engage in share base payment.

Table 3: Presentation of Results: The Fixed Effect

\begin{tabular}{crlrl}
\hline Variable & Coefficient & $\begin{array}{l}\text { Std. } \\
\text { Error }\end{array}$ & t-Statistic & \multicolumn{1}{l}{ Prob. } \\
\hline TAB & -1.101803 & 1.048111 & -1.051228 & 0.2993 \\
\hline ROI & 0.364802 & 0.305401 & 1.194502 & 0.2391 \\
\hline RISK & -0.240735 & 1.087112 & -0.221444 & 0.8258 \\
\hline ME & -0.158620 & 0.123862 & -1.280618 & 0.2075 \\
\hline LIQ & 0.002424 & 0.003204 & 0.756429 & 0.4537 \\
\hline FS & 0.013894 & 0.101810 & 0.136475 & 0.8921 \\
\hline DER & -0.069284 & 0.107056 & -0.647174 & 0.5211 \\
\hline CG & -0.647809 & 1.542201 & -0.420055 & 0.6766 \\
\hline CC & -0.481787 & 1.259064 & -0.382655 & 0.7040 \\
\hline C & 43.48345 & 15.09703 & 2.880265 & 0.0063 \\
\hline R-squared & 0.422356 & & & \\
\hline Adjusted R-squared & 0.168756 & Durbin-Watson stat 2.225778 \\
\hline F-statistic & 1.665442 & & & \\
\hline Prob(F-statistic) & 0.088026 & & & \\
\hline
\end{tabular}

Source: E-view windows 9.0 
www.cribfb.com/journal/index.php/asfbr

Asian Finance \& Banking Review

Vol. 2, No. 1; 2018

The fixed effect Regression Results of variables is table 3 show the details analysis of the effect of the independent variables on the dependent variables. Looking at results it is it is evidenced that the independent variable can explain 42.2\% variation on the dependent variable. The F-statistics and F-probability shows that the model is significant at 5\% level of significance. The Durbin Watson statistics shows a coefficient of less than 2.50 but greater than 2.0 which implies the presence of positive serial auto correlation. The $\beta$ coefficient of the independent variables shows that tangibility, risk, management efficiency, debt equity ratio, corporate governance and cost of capital have negative relationship with the dependent variable while return on investment; liquidity and firm size have positive relationship with the dependent variable. However, the T-statistics and the probability prove that the independent variables are statistically not significant. This implies that variation on the independent variable have no good impact on the dependent variable. This proves that most firms in Nigeria do not adopt the method of share base payment to employees and other stake holders of the firm.

Table 4: Presentation of Results: The Random Effect

\begin{tabular}{crrrl}
\hline Variable & Coefficient & Std. Error & t-Statistic & Prob. \\
\hline C & & & & \\
\hline TAB & 41.101803 & 0.232160 & 1.473609 & 0.0526 \\
\hline ROI & 0.364802 & 0.252097 & 1.022979 & 0.4572 \\
\hline RISK & -0.240735 & 0.006027 & 0.845877 & 0.7885 \\
\hline ME & -0.158620 & 0.227593 & 0.007224 & 0.4171 \\
\hline LIQ & 0.002424 & 0.001599 & 0.000002 & 0.5676 \\
\hline FS & 0.013894 & 0.011750 & 0.001438 & 0.9549 \\
\hline DER & -0.069284 & 0.097781 & 0.002514 & 0.5698 \\
\hline CG & -0.647809 & 0.977813 & 0.243139 & 0.5033 \\
\hline CC & -0.481787 & 1.329340 & 1.006914 & 0.3983 \\
\hline-1.101803 & 0.232160 & 0.473609 & 0.0526 \\
\hline R-squared & 0.420073 & & & \\
\hline Adjusted R-squared & 0.378485 & & & \\
\hline F-statistic & 4.645322 & & & \\
\hline Prob(F-statistic) & 0.027845 & \multicolumn{3}{l}{} \\
\hline
\end{tabular}

Source: E-view windows 9.0

Table 4 shows the Random Effect Regression Results of the independent variables on the dependent variables. Evidence from the random effect as shown in the above table indicates that the independent variables can explain $42.0 \%$ variation on the dependent variable. The F-statistics and F-probability justifies that the model is significant. The Durbin Watson statistics is less than 2.50 but greater than 2.0 justifying the presence of positive serial auto correlation. The $\beta$ coefficient shows that return on investment, risk, firm size debt equity ratio, corporate governance and cost of capital have negative relationship with the dependent variable while tangibility, management efficiency, and liquidity have positive relationship with the dependent variable. The T-statistics and probability shows that the independent variables are statistically not significant.

Test of Hypothesis

Table 5: Presentation of Results: The Fixed Effect

\begin{tabular}{cccccc}
\hline Variable & t-Statistic & Critical T & Prob. & Level Sig & Decision \\
\hline TAB & -1.051228 & $<2.020$ & 0.2993 & $>0.05$ & Accept $\mathrm{H}_{0}$ \\
\hline ROI & 1.194502 & $<2.020$ & 0.2391 & $>0.05$ & Accept $\mathrm{H}_{0}$ \\
\hline RISK & -0.221444 & $<2.020$ & 0.8258 & $>0.05$ & Accept $\mathrm{H}_{0}$ \\
\hline ME & -1.280618 & $<2.020$ & 0.2075 & $>0.05$ & Accept $\mathrm{H}_{0}$ \\
\hline LIQ & 0.756429 & $<2.020$ & 0.4537 & $>0.05$ & Accept $\mathrm{H}_{0}$ \\
\hline FS & 0.136475 & $<2.020$ & 0.8921 & $>0.05$ & Accept $\mathrm{H}_{0}$ \\
\hline DER & -0.647174 & $<2.020$ & 0.5211 & $>0.05$ & Accept $\mathrm{H}_{0}$ \\
\hline CG & -0.420055 & $<2.020$ & 0.6766 & $>0.05$ & Accept $\mathrm{H}_{0}$ \\
\hline CC & -0.382655 & $<2.020$ & 0.7040 & $>0.05$ & Accept $\mathrm{H}_{0}$ \\
\hline
\end{tabular}

Source: E-view windows 9.0 
www.cribfb.com/journal/index.php/asflbr

Asian Finance \& Banking Review

Vol. 2, No. 1; 2018

In testing the significant effect of the variable, the fixed effect model using the T-statistics and the probability coefficient. From the table above, the T-statistics of the ind4ependent variables are less than the critical T-value of \pm 2.020. It therefore rejects the alternate hypothesis and accepts the null hypothesis that there is no significant relationship between corporate characteristics and share base payment of the financial service firms.

5. Conclusion and Recommendations

The determinants of share based payment are those characteristics which are found to have a significant relation in the linkage between companies' characteristics and share based payment. To understand better how the use of share based payment can be a very important method for monitoring employees and decreasing the asymmetry of interest between agent and principal, the effect corporate factors on share based payment has been studied. The negative relation between share based payment and corporate features indicates that the factice of share based payment is not fully practice in most firms. From the findings, the pooled effects could only explain $22.1 \%$ variation on the dependent variable. All the independent variables are statistically not significant. From the fixed effect the independent variables can explain $42.2 \%$ variation on the dependent variable; all the independent variables are statistically not significant while the random effects prove $42.0 \%$ explain variation and the independent variables are statistically not significant. We conclude that corporate characteristics have no significant impact on share base payment of the selected financial service firms. We therefore make the following recommendations.

- The use of share base payment should be adopted in firms where corporate ownership is more of the public sector than the private sector to attract private investors.

- The capital struct6rure of the firms should be optimized to enhance effective management investment policies to encourage share base payment.

- Share base payment should be used if the corporate organizations are not financially prudent for cash payment.

- Policy for share base payment should be integrated and harmonized with the ownership structure of the firms.

References

Alexander et al. (2007). International Financial Reporting and Analysis. 3rd edition.

Anderson, R. C., Duru, A., \& Reeb, D. M. (2009). Founders, heirs, and corporate opacity in the United States. Journal of Financial Economics, 92(2), 205-222.

Ayers, B., \& Freeman, R. (2003). Evidence that analyst following and institutional ownership accelerate the pricing of future earnings. Review of Accounting Studies, 8(1), 47-67.

Atanasova, C., (2007) Access to institutional finance and the use of trade credit. Financial Management 36(1), 4967.

Baik, B. O. K., Farber, D. B., \& Lee, S. A. M. (2011). CEO ability and management earnings forecasts. Contemporary Accounting Research, 28(5), 1645-1668.

Baker, T., Collins, D., \& Reitenga, A., (2003). Stock option compensation and earnings management incentives. Journal of Accounting, Auditing and Finance 18(4), 557-582.

Baker, T. A, Collins, D. L., \& Reitenga, A. L .,(2009). Incentives and opportunities to manage earnings around option grants. Contemporary Accounting Research 26(3), 249-272.

Barry, C., \& Brown, S. (1985). Differential information and security market equilibrium. Journal of Financial and Quantitative Analysis, 20, 407-422.

Benson, B.W., \& Davidson, W. N., (2009) .Reexamining the managerial ownership effect on firm value. Journal of Corporate Finance 15(5), 573-586.

Berle, A. A \& Means, G. C., (1932). The Modern Corporation and private property. New York: Macmillan.

Bettis, J.C, Bizjak, J. M., \& Lemmon, M. L., (2005). Exercise behavior, valuation, and the incentive effects of employee stock options. Journal of Financial Economics 76(2), 445-470.

Blasi et al. (1996). Employee Stock Ownership and Corporate Performance among Public Companies. Industrial and Labor Relations. 50(1), 412-438.

Brav, A, Graham, J.R, Harvey, C.R .,\& Michaely, R., (2005). Payout policy in the 21st century. Journal of Financial Economics 77(3), 483-527.

Brockman, P, Martin, X., \& Unlu, E., (2010). Executive compensation and the maturity structure of corporate debt. The Journal of Finance 65(3), 1123-1161. 
www.cribfb.com/journal/index.php/asflbr

Asian Finance \& Banking Review

Vol. 2, No. 1; 2018

Chakraborty, A., Sheikh, S., \& Subramanian, N., (2007) .Termination risk and managerial risk taking. Journal of Corporate Finance 13(1), 170-188.

Chava, S., \& Purnanandam, A., (2010) CEOs versus CFOs: Incentives and corporate policies. Journal of Accounting and Economics 97(2), 263-278.

Cheng, W., \& Warfield, R.T., (2005). Equity Incentives and Earnings Management. Accounting Review, 80 (2), $441-476,36$

Coles, J. L, Daniel, N. D., \& Naveen, L., (2006). Managerial incentives and risk-taking. Journal of Financial Economics 79(2), 431-468.

Core, J. E., and Guay, W.R. (2001). Stock option plans for non-executive Employees. Journal of Financial Economics, 253-287.

Cuny, C. J., Martin, G. S., \& Puthenpurackal, J. J., (2009). Stock options and total payout. Journal of Financial and Quantitative Analysis 44(2), 391-410.

Dechow, P. M., Kothari, S. P., \& Watts, R. L. (1998). The relation between earnings and cash flows. Journal of Accounting and Economics, 25(2), 133-168.

Diamond, D., \& Verrecchia, R. (1991). Disclosure, liquidity, and the cost of capital. Journal of Finance, 46, 13251360.

Deegan, C., \& Unerman, J., (2006). Financial Accounting Theory. McGraw Hill Education, London.

Demsetz, H., \& Lehn, K., (1985). The structure of corporate ownership: Causes and consequences. Journal of Political Economy 93(6), 1155-1177.

Denis, D. J \& Xu, J ., (2013) .Insider trading restrictions and top executive compensation. Journal of Accounting and Economics 56(1), 91-112.

Dikolli, S. S., Kulp, S. L., \& Sedatole, K. L. (2009). Transient institutional ownership and CEO contracting. The Accounting Review, 84(3), 737-770.

Duncan, W.J (2001). Stock Ownership and Work Motivation. Organizational Dynamics. 30(1), 1-23.

Fahlenbrach, R., \& Stulz, R.M., (2009). Managerial ownership dynamics and firm value. Journal of Financial Economics 92(3), 342-361.

Faulkender, M., Kadyrzhanova, D., Prabhala, N., Senbet, L., (2010). Executive Compensation: An Overview of Research on Corporate Practices and Proposed Reforms. Journal of Applied Corporate Finance,22(12), 5487.

Fenn, G. W., \& Liang, N., (2001). Corporate payout policy and managerial stock incentives. Journal of Financial Economics 60(1), 45-72.

Frydman, C., \& Saks, R. E. (2010). Executive compensation: A new view from a long-term perspective, 1936-2005. Review of Financial Studies, 23(5), 2099-2138.

Guay, W. R., (1999). The sensitivity of CEO wealth to equity risk: an analysis of the magnitude and determinants. Journal of Financial Economics 53(1), 43-71.

Hall, B. J., \& Liebman, J. B., (1998). Are CEOs really paid like bureaucrats? The Quarterly Journal of Economics 113(3), 653-691.

Hayes, R. M, Lemmon, M., \& Qiu, M., (2012). Stock options and managerial incentives for risk taking: Evidence from FAS 123R. Journal of Financial Economics 105(1), 174-190.

Healy, P. M., \& Palepu, K. G. (2001). Information asymmetry, corporate disclosure, and the capital markets: A review of the empirical disclosure literature. Journal of Accounting and Economics, 31(1-3), 405-440.

Himmelberg, C. P, Hubbard, R. G., \& Palia, D. (1999). Understanding the determinants of managerial ownership and the link between ownership and performance. Journal of Financial Economics 53(3), 353-384.

Jensen , M.C., \& Murphy, W., (1990). CEO incentives- It is not how much you pay, but how. Journal of Applied Corporate Finance, 22 (1), 64-76.

Jensen, M. C \& Meckling, W. H., (1976). Theory of the firm: Managerial behavior, agency costs and ownership structure. Journal of Financial Economics 3(4), 305-360.

Jensen, M. C., (1986). Agency costs of free cash flow, corporate finance, and takeovers. American Economic Review 76(2), 323-329.

Johnston, D. (2006). Managing stock option expense: The manipulation of option-pricing model assumptions. Contemporary Accounting Research 23(2), 395-425.

Kahle , K.M., (2002). When a buy back isn't a buyback: open market repurchases and employee options. Journal of Financial Economics 63(2), 235-261.

Knopf, J.D., Nam, J., \& Thornton, Jr, J. H. (2002). The volatility and price sensitivities of managerial stock option portfolios and corporate hedging. The Journal of Finance 57(2), 801-813. 
WwW.cribfb.com/journal/index.php/asflbr

Asian Finance \& Banking Review

Vol. 2, No. 1; 2018

Lewellen, K., (2006).Financing decisions when managers are risk averse. Journal of Financial Economics 82(3), 551-589.

Low, A. (2009). Managerial risk-taking behavior and equity-based compensation. Journal of Financial Economics 92(3), 470-490.

McConnell, J.J, Servaes, H., \& Lins, K. V., (2008). Changes in insider ownership and changes in the market value of the firm. Journal of Corporate Finance 14(2), 92-106.

Milgrom, P. R., \& Roberts, J., (1992). Economics, organization and management, Prentice-Hall Englewood Cliffs, NJ.

Nagar, V., Nanda, D., \& Wysocki, P. (2003). Discretionary disclosure and stock-based incentives. Journal of Accounting and Economics, 34, 283-309.

Noe, C. F. (1999). Voluntary disclosures and insider transactions. Journal of Accounting and Economics, 27(3), 305-326.

Peng and Röell (2008). Manipulation and Equity-Based Compensation. American Economic. 98 (2),285-290.

Rego, S. O., \& Wilson, R., (2012). Equity risk incentives and corporate tax aggressiveness. Journal of Accounting Research 50(3), 775-810.

Rogers, D. A., (2002). Does executive portfolio structure affect risk management? CEO risktaking incentives and corporate derivatives usage. Journal of Banking \& Finance 26(2-3), 271-295.

Ross, S. A. (2004). Compensation, incentives, and the duality of risk aversion and riskiness. The Journal of Finance 59(1), 207-225.

Smith, C., \& Stulz , R., (1985). The determinants of firms' hedging policies. Journal of Financial and Quantitative Analysis 20(4), 391-405.

Yermack, D., (1997). Good Timing: CEO Stock Option Awards and Company News Announcements. Journal of Finance,30(2), 401-423.

Zhou, X .,(2001). Understanding the determinants of managerial ownership and the link between ownership and performance: Comment. Journal of Financial Economics 62(3), 559-571.

\section{Copyrights}

Copyright for this article is retained by the author(s), with first publication rights granted to the journal.

This is an open-access article distributed under the terms and conditions of the Creative Commons Attribution

license (http://creativecommons.org/licenses/by/4.0/) 